\title{
Study of amino acids in Artemisia heptapotamica Poljak and Artemisia albida Willd
}

\author{
U. Mukatay ${ }^{1, *}, M$. Kemelbek ${ }^{1}, A$. Seilkhan $^{2}$, S.A. Ross $^{3}$, and A.A. Zhubanova ${ }^{1}$ \\ ${ }^{1}$ Al-Farabi Kazakh National University, 71 al-Farabi Ave,050040 Almaty, Kazakhstan \\ ${ }^{2}$ Abay Kazakh National pedagogical university, 050010, 13Dostyk, Ave, Almaty, Kazakhstan \\ ${ }^{3}$ University of Mississippi the USA, USA
}

\begin{abstract}
Amino acids are one of the most important categories Natural compounds are structural elements of peptides and polypeptides, which are found in almost all living organisms on the earth. The article uses gasliquid chromatography to study the amino acids in the whole parts of Artemisia heptapotamica Poljak and Artemisia albida Willd collected during flowering. The research results determined the content of 11 amino acids in the raw materials. The main amino acids of Artemisia heptapotamica Poljak are glutamic acid $(2688 \mathrm{mg} / 100 \mathrm{~g})$, aspartic acid $(1340 \mathrm{mg} / 100 \mathrm{~g})$, alanine $(910 \mathrm{mg} / 100 \mathrm{~g})$ and proline $(825 \mathrm{mg} / 100 \mathrm{~g})$, and Artemisia albida willd determined the composition of main amino acids: glutamic $(2662 \mathrm{mg} / 100 \mathrm{~g})$, aspartic $(1320 \mathrm{mg} / 100 \mathrm{~g})$, alanine ( $898 \mathrm{mg} / 100 \mathrm{~g})$ and proline $(809 \mathrm{mg} / 100 \mathrm{~g})$.
\end{abstract}

\section{Introduction}

People paid more attention not only to the nutritional value of plants, but also to their healing side and they have been using for thousands of years in the treatment of some diseases in folk thereapy. the study of the rich flora of Kazakhstan and the identification of new types of plant raw materials the expansion of the raw material base and the development of safe and effective moderen phytopreparations. The medicinal plants have sufficient reserves of raw materials in nature, but the rapid reduction of forest areas due to anthropogenic pressure and unplanned development and excessive use of medicinal plants contribute not only to reduce in their number, but also to the extinction of a number of several species in nature [1], as well as to a decrease in the number of endemic and rare species in biodiversity [2,3], a decrease in populations [4], the extinction of enterded Red Book species $[5,6]$. Currently, many scientists are engaged in the cultivation of medicinal plants in various ways, for example, growing and storing them in the system of organic farming without the use of fertilizers and agricultural drugs. Or growing medicinal plants using new biogums used in agriculture [8]. The reason for the study of plants of the genus Artemisia is due to the presence of a series of biologically active substances artemisinin, guainolide, capillarisin, which is a great achievement for the pharmaceutical industry, but excessive use of raw materials leads to a decrease in plant reserves, as well as it can cause the extinction of endemic species.

* Corresponding author: umit.muhatai@gmail.com 
The content of amino acids in plants varies with the age of plants and external conditions (temperature, day length, humidity) Wait, there is food. This not only changes the concentration of amino acids, but also changes the qualitative composition. The amount of free amino acids decreases as plants age [9].

Recently, amino acids were demonstrated to be useful against diseases such as diabetes, osteoporosis, cardiac diseases, metabolic disturbances, and erectile dysfunction; to have rejuvenating effects; to be useful for menopause conditions; etc.[10, 11]. Wormwoods have rich chemical compositions consisting of essential oils, flavonoids, phenolic acids, tanning agents, fatty acids, amino acids, and many other low-molecular-mass compounds. Plants of the genus Artemisia are just as important among medicinal plants used in official and folk medicine [12]. Artemisia is a plant with a biologically active substance belonging to the genus Asteraceae, which provides prevention of inflammatory diseases of various joints, liver disease, biliary tract, stomach, intestines, rheumatism, microbes, inflammation, skin diseases and bacterial diseases, colds, tuberculosis [13].

The research subjects come from two regions. Artemisia albida Willd is obtained from the Tarbagatai Mountains in eastern Kazakhstan, and Artemisia heptapotamica Poljak Artemisia heptapotamica Poljak is obtained from the Shunzhi region of the Northern Tianshan Mountains of Kazakhstan.

Herein, the whole parts of Artemisia heptapotamica Poljak and Artemisia albida Willd that were collected during flowering were investigated. As a result, twenty amino acids were identified using gas-liquid chromatography.

\section{Materials and Methods}

The conditions for determining the quantitative contents of amino acids were flameionization detector at $300^{\circ} \mathrm{C}$; vaporizer, $250^{\circ} \mathrm{C}$; initial column temperature, $110^{\circ} \mathrm{C}$, and final column temperature $250^{\circ} \mathrm{C}$ with the temperature programmed from 110 to $185^{\circ} \mathrm{C}\left(6^{\circ} \mathrm{C} / \mathrm{min}\right)$ and from 185 to $250^{\circ} \mathrm{C}\left(32^{\circ} \mathrm{C} / \mathrm{min}\right)$. The column was held at $250^{\circ} \mathrm{C}$ until all amino acids had fully eluted.

Amino acids were separated using a stainless-steel column $(400 \times 3 \mathrm{~mm})$ packed with a polar mixture consisting of Carbowax 20M (0.31\%), Silar 5CP $(0.28 \%)$, and Lexan $(0.06 \%)$ on Chromasorb WA-W-120-140 mesh. Chromatograms were processed using an external standard (Altex) [14].

Bound and free amino acids were determined using hydrolysis of the analyzed substance (1 g, Artemisia heptapotamica Poljak and Artemisia albida Willd) in $\mathrm{HCl}$ solution ( $5 \mathrm{~mL}, 6$ $\mathrm{N})$ at $105^{\circ} \mathrm{C}$ for $24 \mathrm{~h}$ in ampouls sealed under a stream of Ar. The obtained hydrolysate was evaporated to dryness in a rotary evaporator at $40-50^{\circ} \mathrm{C}$ and $1 \mathrm{~atm}$. The resulting precipitate was dissolved in C7H6O6S ( $5 \mathrm{~mL}$ ) and centrifuged for $5 \mathrm{~min}$ at $1,500 \mathrm{rpm}$. The supernatant liquid was passed over a column of Dowex 50 ion-exchange resin $(\mathrm{H}-8,200-400$ mesh) at $1 \mathrm{drop} / \mathrm{s}$. The resin was rinsed with deionized $\mathrm{H}_{2} \mathrm{O}(1-2 \mathrm{~mL})$ and $\mathrm{HOAC}(2 \mathrm{~mL}, 0.5 \mathrm{~N})$. Then, the resin was rinsed until the $\mathrm{pH}$ was neutral [15].

Amino acids were eluted from the column by $\mathrm{NH}_{4} \mathrm{ON}$ solution $(3 \mathrm{~mL}, 6 \mathrm{~N})$ at 2 drops $/ \mathrm{s}$. The eluate was collected in a round-bottomed flask together with the distilled $\mathrm{H}_{2} \mathrm{O}$ that was used to rinse the column until neutral. Then, the flask contents were evaporated to dryness in a rotary evaporator at atmospheric pressure and $40-50{ }^{\circ} \mathrm{C}$. Freshly prepared $\mathrm{SnCI}_{2}$ solution (1.5\%), 2,2-dimethoxypropane (one drop), saturated $\mathrm{HCl}$ solution, and $\mathrm{C}_{3} \mathrm{H}_{7} \mathrm{OH}$ (1-2 mL) were added to the flask, heated to $110^{\circ} \mathrm{C}$, and held at that temperature for $20 \mathrm{~min}$. Then, the contents were again evaporated from the flask in a rotary evaporator [16]. 


\section{Results and discussion}

It has been shown that amino acids in all parts of Artemisia heptapotamica Poljak and Artemisia albida Willd collected during flowering can be examined by gas-liquid chromatography. As a result of the study, the content of 11 amino acids in the raw material was determined. The most abundant of these amino acids, glutamate, aspartate, alanine, and proline in the two plants.

Glutamate is one of the most abundant of the amino acids. In addition to its role in protein structure, it plays critical roles in nutrition, metabolism and signaling. Posttranslational carboxylation of glutamyl residues increases their affinity for calcium and plays a major role in hemostasis [17]. Aspartic acid increases immunity, metabolism, deactivates ammonia, participates in the formation of ribonucleic acids, promotes the removal of chemicals, including drugs, restores working capacity. Studies conducted by scientists have proved the effectiveness of taking asparaginic acid preparations for increasing testosterone levels. Aspartic acid is taken as an additive by bodybuilding athletes to improve strength, increase libido and testosterone in the blood [18].

Table 1. Quantitative Contents of Individual Amino Acids in whole parts of Artemisia heptapotamica Poljak and Artemisia albida Willd.

\begin{tabular}{|c|c|c|c|c|c|}
\hline № & $\begin{array}{c}\text { Amino } \\
\text { acids }\end{array}$ & $\begin{array}{l}\text { Molecular } \\
\text { formula }\end{array}$ & Structure & $\begin{array}{c}\text { Amount in } \\
\text { A. } \\
\text { heptapotamica } \\
\text { mg/100g }\end{array}$ & $\begin{array}{l}\text { Amount in } \\
\text { A. albida, } \\
\mathrm{mg} / 100 \mathrm{~g}\end{array}$ \\
\hline 1 & Alanine & $\mathrm{C}_{3} \mathrm{H}_{7} \mathrm{NO}_{2}$ & & 910 & 898 \\
\hline 2 & Glycine & $\mathrm{C}_{2} \mathrm{H}_{5} \mathrm{NO}_{2}$ & & 475 & 462 \\
\hline 3 & Leucine & $\mathrm{C}_{6} \mathrm{H}_{13} \mathrm{NO}_{2}$ & & 452 & 441 \\
\hline 4 & Isoleucine & $\mathrm{C}_{6} \mathrm{H}_{13} \mathrm{NO}_{2}$ & & 414 & 408 \\
\hline 5 & Valine & $\mathrm{C}_{5} \mathrm{H}_{11} \mathrm{NO}_{2}$ & & 350 & 339 \\
\hline 6 & Glutamate & $\mathrm{C}_{5} \mathrm{H}_{9} \mathrm{NO}_{4}$ & & 2688 & 2662 \\
\hline 7 & Threonine & $\mathrm{C}_{4} \mathrm{H}_{9} \mathrm{NO}_{3}$ & & 344 & 333 \\
\hline 8 & Proline & $\mathrm{C}_{5} \mathrm{H}_{9} \mathrm{NO}_{2}$ & & 825 & 809 \\
\hline
\end{tabular}




\begin{tabular}{|c|c|c|c|c|c|}
\hline 9 & Methionine & $\mathrm{C}_{5} \mathrm{H}_{11} \mathrm{NO}_{2} \mathrm{~S}$ & $\mathrm{H}_{3} \mathrm{C}_{\mathrm{NH}_{2}}$ & 120 & 108 \\
\hline 10 & Serine & $\mathrm{C}_{3} \mathrm{H}_{7} \mathrm{NO}_{3}$ & & 382 & 370 \\
\hline 11 & Aspartate & $\mathrm{C}_{4} \mathrm{H}_{7} \mathrm{NO}_{4}$ & & 1340 & 1320 \\
\hline
\end{tabular}

Alanine also increases immunity and provides energy for brain and central nervous system, the muscle tissue. This amino acid protects against the development of cancer of the pancreas and prostate gland [19]. Proline plays important roles in protein synthesis and structure, metabolism (particularly the synthesis of arginine, polyamines, and glutamate via pyrroline-5-carboxylate), and nutrition, as well as wound healing, antioxidative reactions, and immune responses[20]. The results are shown in Table1.

\section{Conclusion}

The amino acid composition of Artemisia heptapotamica Poljak and Artemisia albida Willd was first studied by gas-liquid chromatography. During the study, 11 amino acids were identified from two plants, the main amino acids of which were glutamate, aspartate, alanine and proline. The main amino acids of Artemisia heptapotamica Poljak are glutamate $(2688 \mathrm{mg} / 100 \mathrm{~g})$, aspartate $(1340 \mathrm{mg} / 100 \mathrm{~g})$, alanine $(910 \mathrm{mg} / 100 \mathrm{~g})$ and proline $(825 \mathrm{mg} / 100 \mathrm{~g}$ ), then as Artemisia albida. The main amino acids of the Artemisia albida were: glutamate $(2662 \mathrm{mg} / 100 \mathrm{~g})$, aspartate $(1320 \mathrm{mg} / 100 \mathrm{~g})$, alanine $(898 \mathrm{mg} /$ $100 \mathrm{~g})$ and proline $(809 \mathrm{mg} / 100 \mathrm{~g})$. For comparison, Artemisia heptapotamica Poljak contains more amino acids than Artemisia albida Willd.

\section{References}

1. A. Ydyrys, N. Zhaparkulova, A. Aralbaeva, A. Mamataeva, A. Seilkhan, S. Syraiyl, M Murzakhmetova, Plants, 10(4), 666 (2021) https://doi.org/10.3390/plants 10040666

2. A. Ydyrys, A. Serbayeva, S. Dossymbetova, A. Akhmetova, A. Zhuystay, E3S Web of Conferences, 222(2), 05021 (2020) DOI:10.1051/e3sconf/202022205021

3. A. Ydyrys, N. Mukhitdinov, A. Ametov, B. Tynybekov, A. Akhmetova, K. Abidkulova, World Appl Sc J., 26 (7), 934-940 (2013)

4. A.B. Akhmetova, N.M. Mukhitdinov, A. Ydyrys, A.A. Ametov, Z.A. Inelova, M. Öztürk, Journal of Animal and Plant Sciences, 28(5), 1400-1404 (2018)

5. K. Ummah, Y,S. Rahayu, J. Phys., Conf. Ser. 1417012037 (2019)

6. A. Ydyrys, N. Abdolla, A. Seilkhan, M. Masimzhan, L. Karasholakova, E3S Web of Conferences, 222(1), 04003 (2020) DOI:10.1051/e3sconf/202022204003

7. E.A. Bukenova, Zh.M. Bassygarayev, A.B. Akhmetova, Zh.K. Zhunusbayeva, A. Ydyrys, Research on Crops, 20(1), 210-214 (2019)

8. A. Ydyrys, B. Yeszhanov, N. Baymurzaev, S. Sharakhmetov, A. Mautenbaev, B. Tynybekov, T. Baidaulet, E3S Web of Conferences, 169(2), 02012 (2020) DOI:10.1051/e3sconf/202016902012 
9. A.Ya. Nikolaev, Biological chemistry, 17-19 (M., Medical information agency, 2004)

10. P. Parameswari, R. Devika, Asian J. Pharm. Clin. Res., 9, 183 (2016)

11. H. Fu, J. Wang, Z. Wang, and L. Chen, Chem. Nat. Compd., 47, 675 (2011)

12. J. K. Kim, E.-C. Shin, H.-J. Lim, S. J. Choi, C. R. Kim, S. H. Suh, C.-J. Kim, G. G. Park, C.-S. Park, H. K. Kim J. H. Choi, S.-W. Song, and D.-H. Shin, J. Anal. Methods Chem., 1 (2015)

13. F.D. Dzhumagalieva, E.G. Zarkeshev, Medicinal plants of Kazakhstan and their use in medicine, Alma-Ata, 80-81(1982)

14. X. Gao, Xie WD, Jia ZJ., Journal of Asian Natural Products Research, 10, 185-192 (2008) DOI: 10.1080/10286020701394431 (in Eng)

15. State Pharmacopoeia of the USSR, 11 editions M .: Medicine, 1 (4), 591-596, (1965)

16. P. Adams, J. Chromatography, 188-212 (1974)

17. J.T. Brosnan, M.E. Brosnan, Glutamate: a truly functional amino acid. Amino Acids. (2012) DOI 10.1007/s00726-012- 1280-4 (in Eng)

18. M. Katane, R. Kanazawa, R. Kobayashi, M. Oishi, K. Nakayama, Y. Saitoh, T. Miyamoto, M. Sekine, H. Homma BBA - Proteins and Proteomics, 1865, 1129-1140 (2017) DOI: 10.1016/j.bbapap.2017.06.010 (in Eng)

19. L. Liu, Y. Chen, L. Yang, Analytical Biochemistry, 467, 28-30 (2014) DOI: 10.1016/j.ab.2014.08.035 (in Eng)

20. Wu. Guoyao, Fuller W. Bazer, Robert C. Burghardt, Gregory A. Johnson, Sung Woo Kim, Darrell A. Knabe, Peng Li, Xilong Li, Jason R. McKnight, M. Carey Satterfield, Thomas E. Spencer, Amino Acids 40, 1053-1063, (2011) DOI 10.1007/s00726-0 